\title{
Primary non-Hodgkin follicular lymphoma of the prostate: A case report
}

\author{
Sacit Nuri Görgel ${ }^{1}$, Ertuğrul Şefik², Vural Olğunelma ${ }^{3}$, Evren Şahin ${ }^{3}$, Uğur Balci ${ }^{3}$, Aylin Orgen Çallı $^{4}$
}

${ }^{1}$ Department of Urology, Kahramanmaraş Dr. Süreyya Adanalı Göksun State Hospital Kahramanmaraş, Turkey

${ }^{2}$ Department of Urology, Ardahan State Hospital, Ardahan, Turkey

${ }^{3}$ Department of Urology, İzmir Atatürk Training and Resarch Hospital, İzmir, Turkey

${ }^{4}$ Department of Pathology, İmir Atatürk Training and Resarch Hospital, İzmir, Turkey

Submitted:

01.08 .2012

Accepted:

10.07.2013

Correspondence:

Sacit Nuri Görgel

Department of Urology,

Kahramanmaraş Dr. Süreyya

Adanalı Göksun State Hospital,

46060 Kahramanmaraş, Turkey

Phone: +90 5326882910

E-mail: sngorgel@hotmail.com

CCopyright 2014 by Turkish Association of Urology

Available online at www.turkishjournalofurology.com

\begin{abstract}
Primary lymphoma of the prostate is a rare condition, representing $0.09 \%$ of prostatic malignancies. The clinical presentation of malignant lymphoma of the prostate is difficult to distinguish from other prostatic diseases. Systemic symptoms are rare. Treatments include surgery, chemotherapy and/or radiotherapy. We report a case of primary lymphoma of the prostate in a male patient who presented with lower urinary tract symptoms.
\end{abstract}

Key words: Follicular lymphoma; non-Hodgkin lymphoma; prostate.

\section{Introduction}

Primary lymphoma of the prostate is rare. It represents $0.09 \%$ of all prostate neoplasias, and $0.1 \%$ of all non-Hogdkin lymphomas. ${ }^{[1]}$ Secondary involvement of the gland is the most common presentation in these cases. ${ }^{[2]}$ Moreover, this type of lymphoma tends to occur in elderly men. ${ }^{[3]}$ We report the case of a 74-yearold patient who presented with lower urinary tract symptoms secondary to lymphoma of the prostate. We have discussed the main clinical features, and treatment of this rare condition in the light of the literature.

\section{Case presentation}

A 74-year-old patient presented with lower urinary tract symptoms dating back to 9-month ago. Physical examination was unremarkable. Rectal examination revealed an enlarged prostate. His hematological, liver and renal function test results were within normal limits. His serum prostate-specific antigen was $2.4 \mathrm{ng} / \mathrm{mL}$ (normal: $<4 \mathrm{ng} / \mathrm{mL}$ ). Urinalysis indicated that there was no significant abnormality. On ultrasound examination, the right and left kidneys were normal, and the prostate volume was $106 \mathrm{cc}$. Preoperatively, International Prostate Symptom (IPSS), and quality of life (QOL) scores were 23, and 5 points, respectively. Uroflowmetry revealed a maximum flow rate of $8 \mathrm{~mL}$, and an average flow rate of $4.4 \mathrm{~mL}$. The graph pattern suggested an obstruction. Open prostatectomy was per- formed. Histological, and immunohistochemical studies of the prostatectomy specimen revealed low-intermediate grade non-Hodgkin follicular lymphoma that had originated from the prostate. Presence of a malignant prostate tumor was confirmed by the histopathological examination. Immunohistochemical analysis indicated CD 20 positivity, and CD3, CD 23 negativity (Figure 1). Lymphoma was confined to the prostate with negative surgical margins. Postoperative recovery was uneventful, and the patient was referred to the oncology department for further management. A whole body CT scan was performed after initial diagnosis, and did not reveal any mass or lymphadenopathy. Subsequently, biopsy material was harvested from the right iliac crest, and histopathological examination of the bone marrow biopsy was normal without lymphomatous involvement. Our patient did not receive chemotherapy. He is currently disease free 24 months after the initial presentation and establishment of diagnosis of lymphoma. Preoperatively, written informed consent was obtained from the patient.

\section{Discussion}

Approximately one third of non-Hodgkin lymphomas occur in extranodal sites. Rarely, the prostate may be involved in this condition. These patients tend to be elderly with a mean age of 60 years. ${ }^{[2]}$ Involvement of the prostate in lymphoma usually results in lower urinary tract symptoms, and acute urinary retention. In addition, digital rectal examination may 


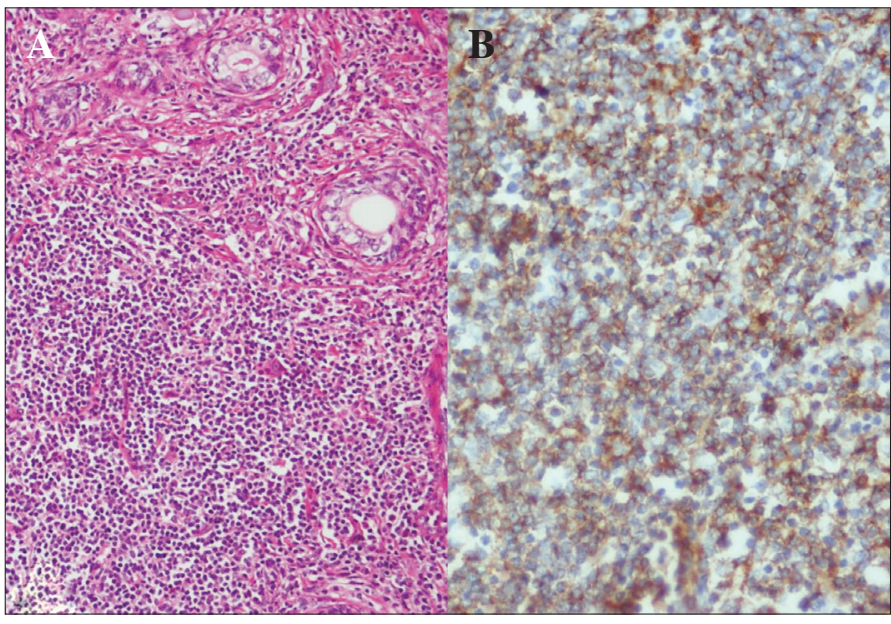

Figure 1.A) Lymphoid cells between the gland tissues (hematoxylin \& eosin, x100); B) immunohistochemical staining with CD20 $(\mathrm{x} 200$

reveal an extremely enlarged prostate with a normal fibroelastic consistency. ${ }^{[4]}$ In our case, a moderately enlarged prostate was detected on digital rectal examination.

Clinical presentation of malignant lymphoma of the prostate is difficult to distinguish from other prostatic diseases that cause lower urinary tract obstructive symptoms. Increased urgency, and frequency of urination, as well as occasional hematuria and acute retention are the most common presenting symptoms. Systemic symptoms are rare. ${ }^{[5]}$

Many studies have shown a range of histopathology among Non-Hodgkin Lymphoma involving the prostate. Diffuse large $\beta$-cell lymphoma of the prostate has been reported by many authors. Other histological patterns have been described as small cell lymphocytic, diffuse small cleaved cell, large cell immunoblastic and polymorphous types. ${ }^{[2]}$ Low grade B-cell mucosa-associated lymphoid tissue lymphoma of the prostate has also been reported. ${ }^{[6]}$ Our patient had a low-intermediate grade non-Hodgkin follicular lymphoma.

The treatment modalities for primary non-Hodgkin follicular lymphoma of the prostate include surgery, chemotherapy and/ or radiotherapy. A rituximab, cyclophosphamide, doxorubicin, vincristine and prednisone regimen is considered to be the standard treatment for patients with advanced diffuse large B-cell lymphoma. ${ }^{[7]}$ The prognosis for primary prostatic lymphoma is uncertain, due to the rarity of the disease. It has been suggested that the prognosis of nodal lymphomas may be similar to that of extranodal lymphomas. ${ }^{[8]}$ Our patient did not receive chemotherapy because of lack of pathological findings in the bone marrow biopsy without a mass lesion or lymphadenopathy.

Informed Consent: Written informed consent was obtained from patients who participated in this case.

Peer-review: Externally peer-reviewed.

Author Contributions: Concept - S.N.G., V.O.; Design - S.N.G., E.S.; Supervision - E.S.; Funding - U.B.; Materials - A.O.Ç.; Data Collection and/or Processing - S.N.G.; Analysis and/or Interpretation - V.O.; Literature Review - E.S., S.N.G.; Writer - S.N.G.; Critical Review - U.B.

Conflict of Interest: No conflict of interest was declared by the authors.

Financial Disclosure: The authors declared that this study has received no financial support.

\section{References}

1. Sarris A, Dimopoulos M, Pugh W, Cabanillas F. Primary lymphoma of the prostate: good outcome with doxorubicin-based combined chemotherapy. J Urol 1995;153:1852-4.

2. Bostwick DG, Mann RB. Malignant lymphomas involving the prostate. A study of 13 cases. Cancer 1985;56:2932-8.

3. Bostwick DG, Iczkowski KA, Amin MB, Discigil G, Osborne B. Malignant lymphoma involving the prostate:report of 62 cases. Cancer 1998;83:732-8.

4. Antunes AA, Dall'Oglio M, Srougi M. Primary lymphoma of the prostate: a rare cause of urinary obstruction. Int Braz J Urol 2004;30:410-2.

5. Tomaru U, Ishikura H, Kon S, Kanda M, Harada H, Yoshiki T. Primary lymphoma of the prostate with features of low grade B lymphoma of mucosa associated lymphoid tissue: a rare cause of urinary tract obstruction. J Urol 1999;162:496-7.

6. Jhavar S, Agrawal JP, Naresh KN, Shrivastava SK, Borges AM, Dinshaw KA. Primary extranodal mucosa associated lymphoid tissue (MALT) lymphoma of the prostate. Leuk Lymphoma 2001;41:445-9.

7. G.Essadi I, Ismaili N, Tazi E, Elmajjaoui S, Saidi A, Ichou M, et al. Primary lymphoma of the head and neck: two case reports and review of literature. Cases J 2008;1:426.

8. Elharroudi T, Ismaili N, Errihani H, Jalil A. Primary lymphoma of the ovary. J Cancer Res Ther 2008;4:195-6. 